\title{
STRATEGI KEPALA SEKSI PENDIDIKAN MADRASAH DALAM MENINGKATKAN MUTU MADRASAH PADA ERA PANDEMI DI KOTA MOJOKERTO
}

\author{
Fairuz Bilah Izzah Hazwani, Iva Septia Sari, Manjah Nurilah \\ UIN Sunan Ampel, Surabaya - Indonesia | fairuzhazwani0@gmail.com
}

\begin{abstract}
Abstrak: The Madrasah Education Section is a sub-division of work that handles the madrasah it supervises. The Madrsah Education Section has a vision of Realizing an Advanced Madrasah, a quality Islamic Education, Forming Intelligent, Creative, Competitive and Islamic People. With this vision, the Madrasah Education Section continues to strive to improve the quality of the madrasah it shelters. This research is a descriptive qualitative study that describes the Sie Pendma Strategy in Improving the Quality of Madrasas in the Pandemic Era in Mojokerto City. The subjects of this study consisted of 1 Head of Madrasah Education Section and 1 Madrasah Education Section staff at the Ministry of Religion Office of Mojokerto City. The data collection techniques used were observation, interview and documentation. The results of this study indicate that, (1) the Head of the Madrasah Education Section has made policies regarding the improvement of the quality of madrasahs, (2) There are special evaluations of madrasah principals which are reported annually and four years on performance during the term of office.
\end{abstract}

Keywords: madrasah quality, policy of the head of the madrasah education section.

\section{Pemdahuluan}

Tidak dipungkiri sebagai makhluk sosial manusia tentu saja tidak jauh dengan kehidupan berkelompok. Manusia yang membentuk kelompok tentu saja mempunyai tujuan tertentu. Ada yang memiliki tujuan yang berbeda dan ada yang mempunyai tujuan yang sama. Jika kelompok tersebut memiliki tujuan yang sama maka disebut dengan organisasi. Terdapat dua definisi dari organisasi yang perlu dipahami, definisi pertama menjelaskan bahwa organisasi sebagai sarana, dan definisi selanjutnya organisasi 
merupakan cara atau jalan seseorang untuk mencapai tujuan yang sama didalam kelompok.1 Dalam sebuah oraganisasi tentu saja ada sebuah unsur yang mempunyai keksusaan tertinggi. Dimana kekusaan tersebut berpengaruh besar bagi perkembangan dan kemajuan dari organisasi tersebut. Sejalan dengan Surah

An-Nisa ayat 59, yang berbunyi:

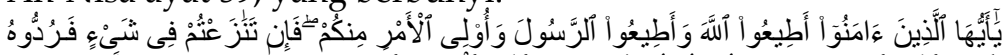

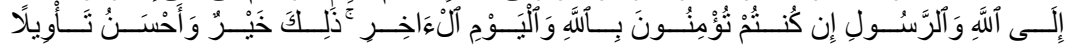

Artinya: Wahai orang-orang yang beriman! Taatilah Allah dan taatilah Rasul (Muhammad), dan Ulil Amri (pemegang kekuasaan) di antara kamu. Kemudian, jika kamu berbeda pendapat tentang sesuatu, maka kembalikanlah kepada Allah (Al-Qur'an) dan Rasul (sunnahnya), jika kamu beriman kepada Allah dan hari kemudian. Yang demikian itu lebih utama (bagimu) dan lebih baik akibatnya. 2

Pemimpin bisa menjadi tolok ukur dalam keberhasilan tujuan organisasi melalui strategi yang biasanya berupa kebijakan yang akan dibuat pada masa kepemimpinannya. Kebijkan bagi seorang pemimpin menjadi sebuah batasan umum dan sarana pemecah masalah yang tejadi dalam organisasi saat ini. Biasanya pemimpin membuat kebijakan bukan hanya secara lisan tetapi ada juga beberapa pemimpin yang memberikan tindakan melalui tindakan sehingga mencapai suatu keputusan.3

Salah satu contohnya Kepala Seksi Pendidikan Madrasah tentu mempunyai kebijakan dalam meningkatkan mutu Madrasah yang unggul, kompetitif dan Islami. Sejalan dengan Visi dan Misi dari Seksi Pendidikan Madrash maka khususnya kepala Seksi Pendidikan Madrasah selalu berupaya untuk meningkatkan mutu pendidikan melalui kebijakan yang telah disepakati bersama dengan para staff yang ada di Seksi Pendidikan Madrasah dengan

${ }^{1}$ Didin Hafidhuddin, Manajemen Syariah dalam Praktek,(Jakarta: Gema Insani, 2003), h.27

${ }^{2}$ QS. An-Nisa/4:59

${ }^{3}$ Amin Priatna, Disertasi “Analisis Implementasi Kebijakan Kesejahteraan Dosen pada Universitas Pendidikan Indonesia, Paca Sarjana UNJ, tahun 2008, h.15 
harapan agar kondisi Madrasah yang dinaunginya dapat berkembang maju sehingga mencapai goals dari Visi yang telah terbentuk.

Dalam penjaminan mutu madrasah tentu tidak lepas dari delapan standar nasional pendidikan yang telah ditetapkan oleh pemerintah. Namun yang paling signifikan yakni, pemberdayaan semua komponen masyarakat dengan mengikutsertakan penyelenggaraan dan pengendalian mutu layanan pendidikan, hal tersebut sejalan pada Bab III pasal 4 ayat 6.4

Semua aspek yang berkaitan dengan penyelenggaraan pendidikan di madrasah akan dinilai. Setelah dinilai akan dilakukan evaluasi serta dianalisa faktor penyebab seperti peran Kementerian Agama terhadap peningkatan mutu pendidikan madrasah baik negeri maupun swasta. Namun pada era pandemi virus corona atau covid 19 saat ini menjadi tantangan lebih bagi Seksi Pendidikan Madrasah Khususnya Kepala Seksi Pendidikan Madrasah. Pasalnya, sudah hampir satu tahun pademi melanda dunia yang berakibatkan berhenti sejenak kehidupan. Kepala Seksi Madrasah harus mampu bertahan bahkan meningkatkan mutu madrasah yang dinaunginya meskipun pada saat ini pembelajaran dilaukan di rumah demi memutus rantai peneyebaran virus corona atau Covid 19, dengan alasan adanya pandemi ini tidak memberhentikan program kerja dalam menjamin keberlangsungan proses penjaminan mutu agar mencapai Visi dan Misi yang diharapkan.

Berdasarkan uraian yang peneliti paparkan tersebut, peneliti ingin mengupas lebih dalam mengenai kebijakan yang diambil oleh Kepala Madrasah dalam meningkatkan mutu madrasah di Kota Mojokerto. Sehingga tujuan dari penelitian ini adalah untuk mengetahui Strategi Kasi Pendma dalam Meningkatkan Mutu Madrasah pada Era Pandemi di Kota Mojokerto.

\section{Metodologi}

Metode penelitian merupakan prosedur-prosedur terencana dalam penelitian. Dalam penelitian ini menggunakan beberapa

\footnotetext{
${ }^{4}$ Undang-Undang Sistem Pendidikan Nasional No 20 tahun 2003.
} 
teknik penelitian yang berhubungan dengan metode penelitian sebagai landasan konseptual. Adapun metode yang digunakan sebagai berikut: Pada penelitian ini, subjek yang menjadi fokus penelitian yaitu sebagian komponen yang ada di Seksi Pendidikan Madrasah Kementerian Agama Kota Mojokerto yang sekaligus sebagai pengumpul data. Adapun data yang tersaji meliputi tahapan diantaranya observasi, wawancara dan dokumentasi. Informan penelitian ini berjumlah 1 (satu) partisipan yang terdiri dari Kepala Seksi Pendidikan Madrasah.

Informan Penelitian berhubungan dengan narasumber yang dimanfaatkan dalam memberikan informasi tentang situasi dan kondisi latar penelitian, dan juga memberi data - data informasi.5 Peneliti pada penelitian ini menentukan informan yakni Kepala Seksi Pendidikan Madrasah, Bapak Bisri Mustofa, s.Ag, MM. berupa data hasil wawancara. Pengelola Kegiatan dan Anggaran Ibu Lisya Indryastutik, S.E. berupa data akreditasi madrasah se-Kota Mojokerto pada Tahun 2019

\begin{tabular}{|c|l|l|l|l|}
\hline No. & \multicolumn{1}{|c|}{ Lembaga } & $\begin{array}{l}\text { Tanggal SK } \\
\text { Akreditasi }\end{array}$ & $\begin{array}{l}\text { Berlaku } \\
\text { Sampai } \\
\text { dengan }\end{array}$ & $\begin{array}{l}\text { Status } \\
\text { Akreditasi }\end{array}$ \\
\hline $\mathbf{1 .}$ & $\begin{array}{l}\text { RA Hidayatullah } \\
2\end{array}$ & $\begin{array}{l}\text { 05 } \\
\text { Desember } \\
2018\end{array}$ & $\begin{array}{l}\text { 05 } \\
\text { Desember } \\
2023\end{array}$ & B \\
\hline $\mathbf{2}$ & RA DEPAG 1 & $\begin{array}{l}05 \\
\text { Desember } \\
2018\end{array}$ & $\begin{array}{l}05 \text { Desember } \\
2023\end{array}$ & B \\
\hline $\mathbf{3}$ & $\begin{array}{l}\text { RA Sunan } \\
\text { Kalijogo }\end{array}$ & $\begin{array}{l}\text { Novemebr } \\
2019\end{array}$ & $\begin{array}{l}\text { Tahun Ajaran } \\
2016 / 2017\end{array}$ & B \\
\hline $\mathbf{4}$ & RA Hidayatulloh & $\begin{array}{l}07 \text { Agustus } \\
2019\end{array}$ & $\begin{array}{l}07 \text { Agustus } \\
2024\end{array}$ & A \\
\hline $\mathbf{5}$ & RA Tarbiyatus & 30 Oktober & Tahun Ajaran & C \\
\hline
\end{tabular}

5 Burhan Bungin, Penelitian Kualitatif, (Jakarta: Prenada Media Group 2011), h. 107 


\begin{tabular}{|c|c|c|c|c|}
\hline & Syibyan & 2010 & $2015 / 2016$ & \\
\hline 6 & RA Ar Rohman & $\begin{array}{l}19 \\
\text { November } \\
2012\end{array}$ & $\begin{array}{l}\text { Tahun Ajaran } \\
\text { 2017/2018 }\end{array}$ & $B$ \\
\hline 7 & Ra DEPAG 2 & $\begin{array}{l}\text { Belum } \\
\text { Akreditasi }\end{array}$ & $\begin{array}{l}\text { Belum } \\
\text { Akreditasi }\end{array}$ & - \\
\hline 8 & MI Al Muhsinun & $\begin{array}{l}05 \\
\text { November } \\
2019\end{array}$ & $\begin{array}{l}05 \text { November } \\
2024\end{array}$ & A \\
\hline 9 & $\begin{array}{l}\text { MI Nurul Huda } \\
2\end{array}$ & $\begin{array}{l}05 \\
\text { November } \\
2019\end{array}$ & $\begin{array}{l}05 \text { November } \\
2024\end{array}$ & A \\
\hline 10 & $\begin{array}{l}\text { MI Nurul Huda } \\
1\end{array}$ & $\begin{array}{l}05 \\
\text { November } \\
2019\end{array}$ & $\begin{array}{l}\text { 05 November } \\
2024\end{array}$ & A \\
\hline 11 & MI Darul Huda & $\begin{array}{l}05 \\
\text { November } \\
2019\end{array}$ & $\begin{array}{l}05 \text { November } \\
2024\end{array}$ & $\mathrm{~A}$ \\
\hline 12 & MI Al-Karimah & $\begin{array}{l}05 \\
\text { November } \\
2019 \\
\end{array}$ & $\begin{array}{l}05 \text { November } \\
2024\end{array}$ & $\mathrm{~B}$ \\
\hline 13 & $\begin{array}{ll}\text { MI } & \text { Sunan } \\
\text { Kalijogo } & \end{array}$ & $\begin{array}{l}23 \\
\text { November } \\
2017\end{array}$ & $\begin{array}{l}23 \text { November } \\
2022\end{array}$ & B \\
\hline 14 & MI GUPPI 2 & $\begin{array}{l}23 \\
\text { November } \\
2017 \\
\end{array}$ & $\begin{array}{l}23 \text { November } \\
2022\end{array}$ & B \\
\hline 15 & MIPABA & $\begin{array}{l}23 \\
\text { November } \\
2017\end{array}$ & $\begin{array}{l}23 \text { November } \\
2022\end{array}$ & A \\
\hline 16 & $\begin{array}{l}\text { MI Hidayatulloh } \\
\text { Plus }\end{array}$ & $\begin{array}{l}27 \text { Oktober } \\
2015\end{array}$ & $\begin{array}{ll}27 & \text { Oktober } \\
2020 & \end{array}$ & B \\
\hline 17 & MTs. Barwijaya & $\begin{array}{l}25 \text { Oktober } \\
2016\end{array}$ & \begin{tabular}{|lr}
25 & Oktober \\
2021 & \\
\end{tabular} & $\mathrm{~B}$ \\
\hline 18 & $\begin{array}{l}\text { MTs. Manbaul } \\
\text { Quran }\end{array}$ & 09 Juli 2019 & 09 Juli 2024 & $\mathrm{~B}$ \\
\hline
\end{tabular}




\begin{tabular}{|c|lc|l|l|l|}
\hline $\mathbf{1 9}$ & $\begin{array}{l}\text { MTs. } \\
\text { Jadid }\end{array}$ & Nurul & $\begin{array}{l}25 \text { Oktober } \\
2016\end{array}$ & $\begin{array}{l}25 \text { Oktober } \\
2021\end{array}$ & B \\
\hline $\mathbf{2 0}$ & $\begin{array}{l}\text { MAN 1 } \\
\text { Mojokerto }\end{array}$ & Kota & $\begin{array}{l}17 \text { November } \\
\text { November } \\
2017\end{array}$ & A \\
& & & & \\
\hline
\end{tabular}

\section{Hasil dan Pembahasan}

Mutu merupakan suatu faktor keputusan mendasar dari pelanggan mutu. Mutu adalah penentuan pelanggan, bukan suatu ketetapan pengguna manajemen. Menurut Edward Sallis, mutu dapat diartikan sebagai sesuatu yang mengenai kepuasan dan melampaui kebutuhan pelanggan.6 Sedangkan mutu menurut Davis dan Goetsch ialah sesuatu yang dinamis yang mana mengikuti dinamika pelanggan dan lingkungan.7

Budaya mutu akan mendorong pada satuan pendidikan dalam meningkatkan mutu pendidikan secara continue atau secara terus menerus dilakukan sehingga mutu dalam pendidikan akan meningkat secara tetap atau konsisten secara bertahap dari waktu ke waktu sehingga standar yang telah diputuskan atau bahkan melebihi standar yang sudah ditentukan. Dalam pendidikan, mutu merupakan syarat utama dalam suatu keberhasilan penyelenggaraan pendidikan nasional. Oleh karena itu harus peningkatan mutu, Peningkatan mutu menjadi semakin penting bagi instansi buat digunakan untuk memperoleh kontrol agar menjadi lebih baik melalui usahanya sendiri.

Dalam menjalankan peningkatan mutu harus ada upaya-upaya atau strategi agar berjalan dengan baik dan tepat sesuai target. Strategi merupakan suatu cara agar mendapatkan sebuah hasil akhir, menggambarkan suatu strategi sebagai arahan untuk dipilih disebuah organisasi untuk mendapatkan suatu capaian misinya. 8

${ }^{6}$ Edward Sallis, Manajemen Mutu Pendidikan, (Yogyakarta: IRCisod, 2008), h. 56

7 Marzuki Mahmud, Manajemen Mutu Perguruan Tinggi, (Jakarta: Rajawali Press, 2012), h. 2

${ }^{8}$ Sandra Oliver, Strategi Public Relations, (Jakarta: PT. Gelora Aksara Pratama, 2006), h. 2 
Diera pandemi corona atau covid 19 sekarang Kementerian Agama Kota Mojokerto terutama di bagian pendidikan madrasah, Kepala seksi bagian pendidikan madrasah telah berkomitmen untuk meningkatkan penjaminan mutu pendidikan dengan menggiatkan, mendorong, memfasilitasi kebutuhan madrasah yang dibutuhkan dan diselenggarakan di madrasah baik negeri maupun madrasah swasta agar dapat berkreasi secara mandiri dengan melaksanakan terobosan - terobosan yang baru, yang mana madrasah diminta untuk meningkatkan kualitas mutu pendidikan, agar madrasah tetap menjadi paling utama pilihan masyarakat untuk pendidikan putra-putrinya agar mencapai tujuan yang pendidikan yang telah ditetapkan oleh pemerintah. Hal tersebut sejalan dengan dengan Peraturan Meneteri Pendidikan Nasional Nomor 63, pasal 2 tentang sistem penaminan mutu pendidikan, yang berisi nahwa tujuan ahkhir dari penjaminan mutu pendidikan yakni meningkatnya angka kercedasan bagi masyarakat di Indonesia sebagai mana layaknya pembukaan Undang-Undang Dasar 1945.9

Berdasarkan penelitian diatas, penulis akan membahas mengenai Strategi KASI PENDMA (Kepala Seksi Pendidikan Madrasah) Kementerian Agama Kota Mojokerto dalam meningkatkan mutu madrasah pada era pandemi yang akan di uraikan sebagai berikut:

- Menyiapkan sumber daya manusia (SDM) dengan memberikan bimbingan (wawasan guru), peningkatan kompetensi yang mana dilakukan 2 kali. Ketika era pandemi ini, maka bimbingan tersebut dilaksanakan secara daring. Dan disesuaikan dengan anggaran yang ada. Jalan tersebut ditempuh pihak Kepala Seksi Pendidikan Madrasah dengan alasan ketika manajemen sumber daya manusia sudah unggul makan produktivitas atau hasil kinerja para guru akan memuaskan sehingga tercapainya tujuan dari pendidikan seperti yang tercantum dalam regulasi yang telah ditetapkan oleh pemerintah.

- Peningkatan Organisasi kepala madrasah (KKM), menyeragamkan, mengkoordinir untuk memberdayakan

\footnotetext{
${ }^{9}$ Permendiknas nomor 63 pasal 2 ayat 1 tentang Sistem Penjaminan Mutu Pendidikan.
} 
mereka (setiap bulan). Hal ini dilakukan di masing-masing rumah kepala madrasah. Kepala seksi bagian pendidikan madrasah (PENDMA) juga memberikan motivasi kepada kepala madrasah agar semangat dan tanggung jawab dalam menjalankan pekerjaan. Dengan adanya program ini akan menjalin kedekatan emosional antara Kepala Seksi Pendidikan Madrasah di Kemeterian Agama Kota Mojokerto dengan Kepala Madrasah yang bersangkutan. Adanya kedekatan emosional tersebut membuat masing-masing kepala madrasah menjadi akan tergugah atau bersemgat dan terus berinovasi dalam meningkatkan kualitas pendidikan madrasah dan lebih terbuka atas kendala kerja yang dihadapinya di madrasah yang dipimpin.

- Dilakukan bimbingan Teknis (BIMTEK) pengelolaan manajerial madrasah, kelembagaan, kurikulum juga sarana dan prasarana yang di tujukan kepada kepala madrasah, dan dilakukan bimbingan kompetensi pembelajaran di era pandemi kepada setiap guru mata pelajaran.

- Kepala seksi bagian pendidikan madrasah (PENDMA) melaksanakan regulasi dari pusat secara maksimal dari sisi pembelajaran daring (menggunakan aplikasi E-learning), sebelumnya harus disosialisasikan kepada guru, siswa dan wali siswa secara terus menerus dan berkelanjutan. Kepala Seksi Pendidikan Madrasah selalu berupayah penuh dalam memenuhi saran dan prasarana yang dibutuhkan oleh pihak madrasah. Dan strategi kepala seksi bagian pendidikan madrasah memberikan terobosan baru pada masa pandemi ini, agar kegiatan belajar mengajar tetap berjalan dengan baik yaitu dengan memberikan bantuan kuota internet kepada setiap murid, guru, dan tenaga kependidikan, yang mana sudah di koordinir terlebih dahulu dengan harapan pembelajaran tetap berjalan dengan lancar dan guru dapat memberi materi sesuai dengan silabus yang mereka susun meskipun masih dalam suasana belajar di rumah atau daring.

- Melakukan evaluasi setiap hari terkait dengan hasil pembelajaran guru dalam mengajar (dipantau melalui aplikasi. 
Seperti: daftar hadir guru saat mengajar, kegiatan guru yang selalu di kontrol melalui fitur aplikasi. Dalam hal ini Kepala seksi bagian pendidikan madrasah (PENDMA) bekerjasama dengan kepala madrasah. Program evaluasi ini penting dilaksanakan agar mengetahui sejauh mana kinerja, produktivitas dari seorang pengajar atau guru. Dengan evalusi juga Kepala Seksi Pendidikan Madrasah dapat mengetahui sejauh mana keberhasilan belajar melalui online atau biasa disebut pembelajaran daring (dalam jaringan). Dalam kegiatan ini Kepala Seksi Pendidikan Madrasah juga memberikan pertimbangan sehingga Kepala Pendidikan Madrasah bisa memperoleh penilaian terhadap proses pembelajaran yang dilakukan antara guru dan siswa-siswi.

Membahas mengenai mutu madrasah, tentunya tidak terlepas dari 8 (delapan) SNP (Standar Nasional Pendidikan), yang mana usaha - usaha yang dilakukan oleh kepala seksi sub bagian pendidikan madrasah kemenag Kota Mojokerto telah melakukan strategis jangka panjang yang telah dilakukan untuk mewujudkan visi dan misi pendidikan nasional terutama di Kota Mojokerto sendiri, seperti antara lain usaha tersebut untuk diwujudkan dalam penetapan SNP (Standar Nasional Pendidikan ), yang jelas dan satu sistem penjaminan dan peningkatan mutu pendidikan yang dapat membangun suatu kerjasama dan kolaborasi dengan berbagai institansi - instansi yang terkait, dalam meningkatkan mutu madrasah, Kepala seksi sub bagian pendidikan madrasah (PENDMA) Kementerian Agama Kota Mojokerto juga menjalankan program-program pendidikan sesuai SNP ( standar nasional pendidikan), diantaranya yaitu:

\section{Standar Isi}

Salah satu cara yang ditempuh untuk meningkatkan mutu madrasah yaitu dengan cara mengikuti kurikulum yang terbaru / selalu memperbarui kurikulum, agar proses belajar di madrasah dapat disesuaikan dengan ruang lingkup materi dan tingkat kompetensi yang akan di tuangkan dalam kriteria tentang kompetensi tamatan, kompetensi bahan kajian, kompetensi mata pelajaran, dan silabus pembelajaran yang mana harus dipenuhi oleh 
peserta didik pada jenjang dan jenis pendidikan di madrasah.10Disini kurikulum disesuaikan dengan pusat K-13 (Kurikulum 2013) yang mana kurikulum saat ini lebih mengutamakan pendidikan karakter (Character Education). Namun yang dihadapi pada saat ini adalah bahwa kegiatan belajar mengajar dialihkan di rumah sehingga menjadi tugas Kepala Seksi Pendidikan Madrasah, sehingga kepala madrasah memberi kebijakan membuat bimbingan kompetensi pembelajaran di masa pandemi virus corona atau covid 19 ini.

\section{Standar Proses}

Meningkatkan mutu madrasah tentunya dapat di tempuh dengan cara meningkatkan mutu guru sebagai pengajar di madrasah, peningkatan model dan media belajar serta meingkatkan kualitas belajar di madrasah. Sesuai standar proses, strategi Kepala seksi sub bagian pendidikan madrasah (PENDMA) Kementerian agama kota mojokerto dalam meningkatkan mutu madrasah dapat ditempuh dengan :

- Melakukan pembinaan kepada kepala madrasah, guru, pegawai dan tenaga kependidikan. Dengan begitu Kepala Seksi sub bagian Pendidikan Madrasah akan meningkatkan kualitas sumber daya manusia di madrasah dengan harapan agar kinerja dari kepala madrasah, guru, pegawai dan tenaga kependidikan akan jauh lebih baik lagi.

- Melakukan evaluasi setiap hari, atau melakukan kontrol pengawasan secara intensif disertai dengan pemberian motivasi kepada kepala sekolah dan guru, agar kepala madrasah dan guru mmepunyai gelora semangat kerja yang tinggi dan menjalin kedekatan emosiona dengan Kepala Seksi Pendidikan Madrasah.

- Mengadakan BIMTEK (Bimbingan Teknis), yang bertujuan untuk menyelesaikan masalah/kasus yang ada. Sehingga penyelesaiannya dapat dipertanggung jawabkan sesuai dengan peraturan perundang-undangan yang berlaku. BIMTEK

\footnotetext{
${ }^{10}$ Suhirman Dan Idi Syatriawan, 2017, Strategi Kementerian Agama Dalam Meningkatkan Mutu Manajemen Madrasah Aliyah Di Kabupaten Seluma, (Bengkulu : Institut Agama Islam NegeriBengkulu ), 118.
} 
(bimbingan teknis) di lakukan dengan SATKER (Satuan Kerja) terkait, dan pelaksanaannya secara tatap muka / dengan metode ceramah. Akan tetapi di era pendemi ini BIMTEK (bimbingan teknis) dilakukan secara daring.

- Melakukan workshop atau training (pelatihan), workshop disini pelatihan bagi guru untuk dapat meningkatkan kompetensinya

\section{Standar Kompetensi Lulusan}

Salah satu hal yang dapat dilakukan guna meningkatkan mutu madrasah yaitu meningkatkan mutu belajar didalam madrasahnya itu sendiri, dikarenakan peningkatan mutu belajar dalam madrasah dilaksanakan sebagai upaya peningkatan kelulusan siswa. Strategi Kepala seksi pendidikan madrasah (PENDMA) dalam meningkatkan mutu madrasah jika dilihat dari standar kompetensi lulusan dapat ditempuh dengan langkah-langkah sebagai berikut:

- Meningkatkan mutu jenjang pendidikan sesuai dengan perkembangan teknologi

- Pembinaan madrasah negeri diusahakan menjadi contoh bagi madrasah swasta terutama soal mutu pendidikannya.

- Selalu melakukan evaluasi kepada setiap madrasah agar pendidikannya selaras dengan sistem pendidikan nasional.

\section{Standar Pendidik dan Tenaga Kependidikan}

Standar Pendidik dan Tenaga Kependidik merupakan standar nasional tentang kriteria pendidikan prajabatan dan kelayakan fisik maupun mental

serta pendidikan dalam jabatan dari tenaga guru dan tanaga kependidikan lainnya. Pendidik harus memiliki kualifikasi akademik dan kompetensi sebagai agen pembelajaran, sehat jasmani dan rohani, serta memiliki kemampuan untuk mewujudkan tujuan pendidikan nasional.11

Strategi yang dilakukan oleh Kepala seksi sub bagian pendidikan madrasah (PENDMA) di Kemenag Kota Mojokerto dalam peningkatan mutu manajemen Madrasah melalui beberapa kegiatan seperti, pembinaan, bintek, workshop dan diklat serta

\footnotetext{
${ }^{11}$ Suhirman Dan Idi Syatriawan, 2017, Strategi Kementerian Agama Dalam Meningkatkan Mutu Manajemen Madrasah Aliyah Di Kabupaten Seluma, (Bengkulu : Institut Agama Islam NegeriBengkulu ), 121.
} 
melakukan supervise dan monitoring, melakukan kegiatan evaluasi melalui kerjasama dengan forum kedinasan terkait. Peningkatan mutu Madrasah tidak bisa dilakukan hanya oleh Kepala seksi pendidikan madrasah (PENDMA) saja tanpa bantuan dan peran aktif dari berbagai pihak terkait lainnya.

\section{Standar Sarana dan Prasarana}

Standar sarana dan prasarana merupakan standar nasional pendidikan yang berkaitan dengan kriteria minimal tentang ruang belajar, tempat berolahraga, tempat beribadah, perpustakaan, laboratorium dan sumber belajar lainnya sebagai penunjang proses pembelajaran termasuk penyediaan teknlogi. Kepala seksi bagian pendidikan madrasah (PENDMA) memenuhi kebutuhan sarpras lembaga supaya output siswa dapat meningkat. Seperti halnya saat era pandemi ini, Kepala seksi bagian pendidikan madrasah (PENDMA) menyediakan bantuan berupa paket data internet untuk siswa/siswi mulai dari jenjang MI (Madrasah Ibtidaiyah) sampai MA (Madrasah Aliyah), guna untuk proses pembelajaran secara daring.

\section{Standar Kompetensi Pengelolaan}

Tugas pokok dan fungsi seksi pendidikan Madrasah adalah Melaksanakan pelayanan, bimbingan, Pembinaan dan Pengelolaan sistem informasi dibidang pendidikan agama Islam :

- penyiapan perumusan kebijakan teknis dan perencanaan di bidang pendidikan Madrasah;

- pelaksanaan pelayanan, bimbingan dan pembinaan bidang kurikulum dan evaluasi, pendidik dan tenaga kependidikan, sarana prasarana, pengembangan potensi siswa, kelembagaan kerjasama, dan pengelolaan sistem informasi pendidikan madrasah.

- evaluasi dan penyusunan laporan di bidang pendidikan Madrasah

- Dalam hal ini Kepala Madrasah bertugas melakukan pengawasan proses pendidikan dan pengelolaan madrasah, sedangkan guru bertugas sebagai perancang proses pembelajaran serta mampu menata dan mengelola kelas.

\section{Standar Kompetensi Pembiayaan}


Strategi PENDMA (Pendidikan Madrasah) dalam meningkatkan mutu madrasah jika dilihat dari kompetensi pembiayaan antara lain : yaitu pemberian dana BOS (Bantuan Operasional Sekolah). Bantuan Opersional Sekolah (BOS) adalah program yang bertujuan untuk membebaskan segala jenis biaya pendidikan bagi seluruh siswa miskin di tingkat pendidikan dasar, menengah, atas baik di madrasah negeri maupun madrasah swasta. Program ini ditujukan untuk seluruh murid madrasah di Kota Mojokerto yang menyelenggarakan program Wajar Dikdas. Adapun kegiatankegiatan yang dilakukan dalam program ini adalah:

- Memeriksa proposal pengajuan BOS (Bantuan Operasional Sekolah) mengetahui kepala madrasah

- Merekap data/berkas

- Berkas lengkap (ACC)

- Pencairan : seperti BOP (Bantuan Operasional Penyelenggara) alokasinya. Pencairan 2 kali dalam setahun

- MI : Rp. 900.000 per tahun

○ MTs : Rp. 1.100 .000 per tahun

○ MA : Rp. 1.300 .000 per tahun

Tahap 1 pencairannya bulan april dan tahap 2 bulan september.

- LPJ periode sebelumnya.

BOS (Bantuan Operasional Sekolah) dinilai dapat memberikan dampak positif bagi lembaga. (1) pihak sekolah sudah tidak memikirkan kekurangan biaya operasional sekolah lagi dan tentunya anak-anak Indonesia dapat mengakses sekolah. Depdiknas harus memaksa sekolah untuk meningkatkan kualitas dan layanan sekolah. (2) sejak diluncurkan program BOS (Bantuan Operasional Sekolah) terjadi peningkatan kualitas pendidikan sehingga sekolah yang kualitasnya masih rendah makin lama makin sedikit. (3) Program BOS (Bantuan Operasional Sekolah) juga meningkatkan penerimaan sekolah. Dengan dana BOS (Bantuan Operasional Sekolah), sekolah dapat meningkatkan ketersediaan sarana dan prasarana belajar-mengajar, pendapatan guru (guru honor, guru kontrak, dan guru tetap), kegiatan ekstrakurikuler, pelajaran tambahan, dan mutu guru. Bahwa program BOS (Bantuan 
Operasional Sekolah) juga ditujukan untuk mencegah anak putus sekolah.12

Selanjutnya Kepala seksi bagian pendidikan madrasah (PENDMA) juga memberikan bantuan berupa Program Indonesia Pintar ( PIP ). Program Indonesia Pintar ( PIP ) adalah program yang bertujuan untuk meningkatkan angka partisipasi pendidikan dasar dan menengah. Program ini ditujukan untuk semua anak usia sekolah yang kurang mampu. Adapun kegiatan yang dilakukan dalam program ini adalah:

- Memeriksa proposal pengajuan PIP mengetahui kepala madrasah

- Merekap data/berkas

- Memverifikasi data

- Berkas lengkap ( ACC)

- Pencairan

- LPJ.

\section{Standar Kompetensi Penilaian}

Standar Penilaian adalah standar nasional yang berkaitan dengan mekanisme, prosedur, dan mekanisme penilaian hasil belajar yang dilakukan oleh peserta didik. Standar penilaian pendidikan merupakan acuan nasional pendidikan berhubungan dengan teknis, cara, dan form penilaian hasil belajar dari siswasiswi.13 Untuk Penilaian Kepala seksi bagian pendidikan madrasah (PENDMA) Kemenag Kota Mojokerto di tujukan kepada seluruh kepala madrasah yang ada di kota mojokerto beserta guru dan tenaga kependidikan lainnya. Untuk kepala madrasah penilaian/ evaluasi bersifat jangka pendek (per tahun satu kali) dan menengah (setiap 4 tahun sekali), kepala madrasah dinilai berdasarkan dari kompetensi Kepribadian, Kompetensi Manajerial, Kompetensi Entrepreneur / Kewirausahaan, Kompetensi Supervisi dan Kompetensi Sosial nya. Untuk Guru yang dinilai yaitu Kompetensi

\footnotetext{
${ }^{12}$ Suhirman Dan Idi Syatriawan, 2017, Strategi Kementerian Agama Dalam Meningkatkan Mutu Manajemen Madrasah Aliyah Di Kabupaten

Seluma, (Bengkulu : Institut Agama Islam NegeriBengkulu ), 121.

${ }_{13}$ Peraturan Menteri Pendidikan Nasional Nomor 20 Tahun 2007 Tanggal 11 Juni 2007 Standar Penilaian Pendidikan.
} 
pedagogik, kompetensi kepribadian, kompetensi profesional dan kompetensi sosial. Sedangkan standar penilaian oleh guru kepada para siswa nya ditempuh dengan beberapa cara yaitu : dengan di adakannya Ulangan harian, ulangan tengah semester, ulangan akhir semester, ulangan kenaikan kelas, ujian sekolah / madrasah ujian nasional yang selanjutnya di sebut UN dan kriteria ketuntasan minimal (KKM).

\section{Kesimpulan}

Berdasarkan hasil penelitian dan pembahasan, maka simpulannya adalah strategi kepala seksi pendidikan madrasah di Kota Mojokerto pada era pandemi corona atau covid 19 sekarang dalam meningkatkan mutu madrasah tidak jauh berbeda sebelum adanya pandemi, perbedaanya hanya di tempat dan waktu pelaksanaannya, yaitu yang mana sebelum pandemi dalam menyiapkan sumber daya manusia (guru) dengan memberikan bimbingan (wawasan guru), peningkatan kompetensi yang biasannya dilakukan 2 kali. Ketika era pandemi ini, maka bimbingan tersebut dilaksanakan secara daring dengan melalui aplikasi Zoom, google meet, dan aplikasi lain - lainnya.

Strategi selanjutnya yaitu mengkoordinir, menyamaratakan untuk memberdayakan kepala sekolah yang dilakukan setiap bulan, yang mana strategi ini kepala seksi pendidikan madrasah kemenag Kota Mojokerto memberikan motivasi untuk meningkatkan kinerja kepala madrasah agar semangat dan bertanggung jawab dalam menjalankan pekerjaannya. Strategi bimbingan teknis (BIMTEK) dalam pengelolaan manajerial madrasah, kelembagaan, kurikulum juga sarana dan prasarana yang di tujukan kepada kepala madrasah, dan dilakukan bimbingan kompetensi pembelajaran di era pandemi kepada setiap guru mata pelajaran.

Selain meningkatkan kinerja kepala sekolah, Kepala seksi pendidikan madrasah kemenag Kota Mojokerto juga melakukan evaluasi setiap hari terkait dengan hasil pembelajaran guru dalam mengajar yaitu dengan dipantau melalui aplikasi. Seperti: daftar hadir guru saat mengajar) dengan mengevaluasi lewat (daftar hadir) aplikasi absensi yang mana biasannya langsung disekolahan, 
dikarenakan sekarang adanya pandemi, maka absensi dilakukan melalui aplikasi, Kepala seksi bagian pendidikan madrasah (PENDMA) dalam hal ini bekerjasama dengan kepala madrasah. Dalam segi pembelajaran pada masa pandemi ini dilakukan dengan pembelajaran daring yang mana menggunakan aplikasi E-learning, sebelumnya sudah disosialisasikan secara terus - menerus kepada pihak yang berkaitan seperti (guru, orang tua, murid, dll).

Pada masa pandemi sekarang kepala seksi bagian pendidikan madrasah kemenag Kota Mojokerto memberikan terobosan baru agar kegiatan belajar mengajar tetap berjalan dengan baik yaitu dengan memberikan bantuan kuota internet kepada setiap murid, guru, dan tenaga kependidikan.Dalam menjalankan strategi kepala seksi pendidikan madrasah kemenag Kota Mojokerto untuk meningkatkan mutu pendidikan juga menjalankan programprogram yang ada di delapan standar pendidikan nasional sesuai dengan kurikulum 2013 yang meliputi standar isi, standar proses, standar sarana dan prasarana, standar kompetensi kelulusan, standar kompetensi pengelolaan, standar kompetensi pembiayaan, standar kompetensi pendidik dan tenaga kependidikan serta standar kompetensi penilaian

\section{References}

Bungin Burhan. 2011. Penelitian Kualitatif. (Jakarta: Prenada Media Group)

Hafidhuddin Didin. 2003. Manajemen Syariah dalam Praktek. (Jakarta: Gema Insani)

Idi Syatriawan Dan Suhirman. 2017. Strategi Kementerian Agama

Dalam Meningkatkan Mutu Manajemen Madrasah Aliyah

Di Kabupaten Seluma. (Bengkulu : Institut Agama Islam Negeri Bengkulu)

Mahmud Marzuki. 2012. Manajemen Mutu Perguruan Tinggi. (Jakarta: Rajawali Press)

Oliver Sandra. 2006. Strategi Public Relations. (Jakarta: PT. Gelora Aksara Pratama) 
Sallis Edward. 2008. Manajemen Mutu Pendidikan. (Yogyakarta: IRCisod)

Priatna Amin. 2008. Disertasi Analisis Implementasi Kebijakan Kesejahteraan Dosen pada Universitas Pendidikan Indonesia, Paca Sarjana UNJ

Undang-Undang Sistem Pendidikan Nasional No 20 tahun 2003 